\title{
Revegetation of waste fly ash landfills in a semiarid environment
}

\author{
GARY M. PIERZYNSKI, JOSHUA L. HEITMAN, PETER A. KULAKOW, GERARD J. KLUITENBERG, AND \\ JAMES CARLSON
}

Professor, graduate research assistant, research assistant professor, and professor, respectively, at Dept. of Agronomy, Kansas State University, Manhattan, Kan. 66506, Environmental Supervisor, Sunflower Electric Corporation, Garden City, Kan.

\section{Abstract}

This study investigated vegetation strategies for a fly ash landfill in a semi-arid environment. Ten plant species adapted to the local climate were initially evaluated for their germination characteristics in various mixtures of Tivoli fine sand, fly ash, and cattle manure. Alkali sacaton (native, Sporobolus airoides (Torr.) Torr.), blue grama (native, Bouteloua gracilis (H.B.K.) Lag. Ex Griffiths), a forage sorghum (variety Canex, Sorghum bicolor (L.) Moench), sand bluestem (variety Woodward, Andropogon hallii Hack.), and sideoats grama variety El Reno, Bouteloua cur. tipendula (michx.) Torr.) were selected for further evaluation. Concurrently, mixtures were evaluated to determine the effects of the soil amendments on soil saturated paste electrical conductivity (EC) and $\mathrm{pH}$. The addition of even $50 \mathrm{~g} \mathrm{~kg}^{-1}$ fly ash increased EC values above $4.0 \mathrm{dS} \mathrm{m}^{-1}$, indicating salt tolerant species may be needed. Six mixtures were selected for use in a greenhouse study and for further study of moisture retention characteristics. Using an $X / Y$ format, where $X$ is fly ash content and $Y$ is manure content $\left(\mathrm{g} \mathrm{kg}^{-1}\right)$ and the balance of the mixture was Tivoli fine sand, those mixtures were $0 / 0,200 / 0,200 / 100$, $200 / 200,100 / 100$, and $300 / 100$. The addition of manure provided ample quantities of plant nutrients. Alkali sacaton was the only plant specie not adversely affected by the addition of fly ash. For biomass production, height, vigor and leaf tip burn, all remaining species had significantly better growth or ratings with $0 / 0$ as compared to any other mixture. Soil moisture retention characteristics of the Tivoli fine sand can be significantly changed through amendment with fly ash or manure. Sixty $\mathrm{cm}$ of Tivoli sand was estimated to have the same available water holding capacity as $45 \mathrm{~cm}$ of $200 / 0,39 \mathrm{~cm}$ of $200 / 100,34 \mathrm{~cm}$ of $200 / 200,47$ $\mathrm{cm}$ of $100 / 100$, and $33 \mathrm{~cm}$ of $300 / 100$.

Key Words: salinity, plant nutrients, germination, available water capacity

Fly ash is produced in significant quantities as a result of combustion of coal for electric power generation and the disposal of that fly ash represents a significant challenge for power generating stations. Beneficial uses include incorporation into cement/concrete mixtures or asphalt and road-bed stabilization. The remainder of the material is generally handled as a suspen-

\footnotetext{
Contribution No. 03-225-J from the Kansas Agricultural Experiment Station, Manhattan, Kan.

Manuscript accepted 16 Aug. 2003.
}

Este estudio investigó estrategias de vegetación para un relleno de cenizas volantes (ceniza de carbón utilizado para generar energía) en un ambiente semiárido. Diez especies de plantas adaptadas al clima local inicialmente se evaluaron para determinar su características de germinación en varias mezclas de arena fina Tivoli, ceniza volante y estiércol de bovino. El "Alkali sacaton" (Sporobolus airoides (Torr.) Torr., nativo), "Blue grama" (Bouteloua gracilis (H.B.K.) Lag. Ex Griffiths nativo), un sorgo forrajero (Sorghum bicolor (L.) Moench, variedad Canex ), "Sand bluestem" (Andropogon hallii Hack., variedad Woodward) y "Sideoats grama" (Bouteloua curtipendula (michx.) Torr., variedad El Reno) fueron seleccionadas para una evaluación posterior. Al mismo tiempo las mezclas se evaluaron para determinar sus efectos como mejoradores de suelo en la conductividad eléctrica (CE) y pH en la pasta de saturación del suelo. Aun la adición $50 \mathrm{~g} \mathrm{~kg}^{-1}$ ceniza volante incrementó los valores de CE a más de $4.0 \mathrm{dS} \mathrm{m}^{-1}$, indicando que se pude requerir de especies tolerante a salinidad. Seis mezclas se seleccionaron para usarlas en un estudio de invernadero y para un estudio posterior de características de retención de agua. Usando un formato $X / Y$, donde $X$ es el contenido de ceniza volante y el de estiércol $\left(\mathrm{g} \mathrm{kg}^{-1}\right)$ y el balance de la mezcla fue la arena fina Tivoli, esas mezclas fueron: $0 / 0,200 / 0,200 / 100,200 / 200,100 / 100$ y 300/100. La adición de estiércol proveyó amplias cantidades de nutrientes para las plantas. La única especie que no fue afectada adversamente por la adición de ceniza volante fue el "Alkali sacaton". Respecto a la producción de biomasa, altura, vigor y quemadura de la punta de la hoja, el resto de las especies tuvieron un mejor crecimiento en la mezcla $0 / 0$ que en cualquier otra mezcla. Se estimó que las características de retención de humedad de la arena fina Tivoli pueden ser cambiadas significativamente a través del mejoramiento del suelo con ceniza volante o estiércol Se estimó que $60 \mathrm{~cm}$ de arena Tivoli tienen la misma capacidad de retención de agua disponible que $45 \mathrm{~cm}$ de $200 / 0,39 \mathrm{~cm}$ de $200 / 100,34 \mathrm{~cm}$ de $200 / 200,47 \mathrm{~cm}$ de $100 / 100$ y $33 \mathrm{~cm}$ de $300 / 100$.

sion and stored in ash dams, or handled as a dry material with storage in landfills. These latter 2 options generally require a vegetative cover when the storage areas are closed to prevent dust generation and for aesthetics. Fly ash itself is a poor growth medium because of salinity, the presence of potentially phytotoxic elements, and limitations in physical properties (El-Magazi et al. 1988, Page et al. 1979). State and federal requirements dictate that the storage areas be covered with soil, sometimes up to 60 
$\mathrm{cm}$ deep, and then revegetated at closure.

Revegetation can be challenging in a semi-arid environments in general, and in particular if the soil available for cover has chemical or physical limitations. The impetus for this research was the Sunflower Electric Corporation near Garden City, Kansas USA, which is facing the challenge of closing waste fly ash landfills using a minimum of $60 \mathrm{~cm}$ of soil cover according to state requirements. The power generating station is sited on a large tract of land mapped as a Tivoli fine sand (Mixed, thermic Typic Ustipsamments) that would be the only soil available for use as cover. Tivoli fine sand has low fertility and excessive internal drainage, and is not well suited for establishing or maintaining permanent vegetative cover. When not vegetated, it reverts to active sand dunes (Soil Survey 1965). Average annual precipitation is $48 \mathrm{~cm}$. Fly ash is the fraction of coal combustion residue that leaves the boiler in the flue gas. The station burns low sulfur western sub-bituminous coal. Amending the Tivoli fine sand with fly ash and/or cattle manure (locally available from the cattle feeding industry) offers the opportunity to improve soil physical characteristics and fertility, and may reduce the depth of cover required to maintain vegetation.

The use of fly ash as a soil amendment has been shown to increase soil $\mathrm{pH}$ and salinity and have no effect on extractable phosphorus (P) concentrations (Matsi and Keramidas 1999). Other research has demonstrated significant P-fixing ability from bottom ash/fly ash mixtures, presumably because of the precipitation of $\mathrm{P}$ with $\mathrm{Ca}$ (Gray and Schwab 1992). The authors hypothesized that up to $1000 \mathrm{~kg} \mathrm{P} \mathrm{ha}^{-1}$ would need to be added to prevent $\mathrm{P}$ deficiencies in plants. Fly ash has also been viewed as a source of plant nutrients such as calcium (Ca), boron (B), sulfur (S), and molybdenum (Mo) (Sajwan et al. 1995).

Land application of fly ash has been suggested as a means to favorably alter soil physical properties for vegetative establishment and production (Adriano et al. 1980, Gangloff et al. 2000, Adriano and Weber 2001). This effect on soil physical properties has been connected to changes in pore size distribution upon addition of fly ash material (Chang et al. 1977, Ghodrati, et al. 1995). Research has shown that the addition of fly ash has resulted in reduced saturated hydraulic conductivity and increased available water capacity (Campbell et al. 1983, Ghodrati et al. 1995, Gangloff et al. 2000, Adriano and Weber 2001). Changes in these prop- erties, in turn, offer decreased drainage losses and increased storage and drought tolerance. Concerns, however, have been presented over the potential for increased erosion where fly ash is applied at the surface (Lehrsch and Baker 1989, Gorman et al. 2000). Realizing potential benefits of fly ash application to soil physical properties therefore requires careful consideration of maximum layer thickness.

The objectives of this study were to identify native plant species that would be suitable as a vegetative cover for a waste fly ash landfill in a semi-arid environment; to determine the suitability of various mixtures of Tivoli fine sand, fly ash, and cattle manure as a plant growth media for the candidate species; and to determine changes in available water capacity of the Tivoli fine sand upon amendment with various amounts of fly ash and cattle manure. This information was then used to estimate the available water capacity of hypothetical soil covers, 30-, 45-, and 60$\mathrm{cm}$ in thickness, consisting of various mixtures of Tivoli fine sand, fly ash, and cattle manure.

\section{Materials and Methods}

The experiments can be divided into 3 general categories: 1) incubation and germination, 2) greenhouse, and 3) available water capacity. For all experiments, Tivoli fine sand and fly ash were collected from the Holcomb Station of the Sunflower Electric Corporation facility and stockpiled cattle manure was collected from the

Table 1. Saturated paste $\mathrm{pH}$ and electrical conductivities as influenced by time $(t)$ and the proportion of sand, fly ash, and manure in the mixture. Means within a column with the same letter are not statistically different by LSD at $\mathrm{P} \leq \mathbf{0 . 0 5}$.

\begin{tabular}{|c|c|c|c|c|c|c|}
\hline \multirow[t]{2}{*}{ Mixture } & \multicolumn{3}{|c|}{ - } & \multicolumn{3}{|c|}{ - } \\
\hline & $t=3 \mathrm{~d}$ & $t=10 \mathrm{~d}$ & $t=30 \mathrm{~d}$ & $t=3 \mathrm{~d}$ & $t=10 \mathrm{~d}$ & $t=30 \mathrm{~d}$ \\
\hline & & & & \multicolumn{3}{|c|}{ - } \\
\hline $0 / 100^{1}$ & $7.7 \mathrm{i}$ & $7.5 \mathrm{~g}$ & $7.2 \mathrm{j}$ & $1.3 \mathrm{i}$ & $1.8 \mathrm{j}$ & $2.8 \mathrm{~g}$ \\
\hline $50 / 50$ & $8.7 \mathrm{bcd}$ & $8.6 \mathrm{~cd}$ & $8.4 \mathrm{~g}$ & $4.1 \mathrm{~g}$ & $4.6 \mathrm{~h}$ & $5.8 \mathrm{ef}$ \\
\hline $100 / 0$ & $8.8 \mathrm{a}$ & $8.7 \mathrm{ab}$ & $8.7 \mathrm{~cd}$ & $4.6 \mathrm{f}$ & $5.1 \mathrm{~g}$ & $6.2 \mathrm{ef}$ \\
\hline $0 / 200$ & $7.7 \mathrm{i}$ & $7.3 \mathrm{~h}$ & $7.0 \mathrm{k}$ & $2.0 \mathrm{~h}$ & $3.2 \mathrm{i}$ & $5.4 \mathrm{f}$ \\
\hline $50 / 150$ & $8.4 f$ & $8.2 f$ & $8.2 \mathrm{~h}$ & $5.2 \mathrm{e}$ & $7.2 f$ & $8.3 \mathrm{~d}$ \\
\hline $100 / 100$ & $8.6 \mathrm{~cd}$ & $8.5 \mathrm{de}$ & $8.5 f$ & $5.2 \mathrm{e}$ & $7.7 f$ & $8.1 \mathrm{~d}$ \\
\hline $150 / 50$ & $8.7 \mathrm{~b}$ & $8.6 \mathrm{~cd}$ & $8.6 \mathrm{df}$ & $5.8 \mathrm{~d}$ & $8.3 e$ & $8.8 \mathrm{~cd}$ \\
\hline $200 / 0$ & $8.9 a$ & $8.7 a b c$ & 8.7abc & $6.0 \mathrm{~d}$ & $9.6 \mathrm{~b}$ & $9.7 b$ \\
\hline $0 / 300$ & $7.8 \mathrm{~h}$ & $7.5 \mathrm{~g}$ & $7.0 \mathrm{k}$ & $2.5 \mathrm{~h}$ & $4.5 \mathrm{~h}$ & $6.4 \mathrm{e}$ \\
\hline $50 / 250$ & $8.3 \mathrm{~g}$ & $8.2 \mathrm{f}$ & $8.0 \mathrm{i}$ & $7.0 \mathrm{c}$ & $8.3 \mathrm{e}$ & $9.5 b$ \\
\hline $100 / 200$ & $8.5 \mathrm{e}$ & $8.4 \mathrm{e}$ & $8.2 \mathrm{~h}$ & $7.2 \mathrm{c}$ & $8.9 \mathrm{~d}$ & $9.7 \mathrm{~b}$ \\
\hline $150 / 150$ & $8.6 \mathrm{~d}$ & $8.6 \mathrm{bcd}$ & $8.6 \mathrm{ef}$ & $6.9 c$ & $9.4 \mathrm{~b}$ & $9.6 \mathrm{bc}$ \\
\hline $200 / 100$ & $8.7 \mathrm{bcd}$ & $8.7 \mathrm{ab}$ & $8.7 b c$ & $7.7 \mathrm{~b}$ & $9.1 \mathrm{~d}$ & $9.9 b$ \\
\hline $250 / 50$ & $8.7 b c$ & $8.8 \mathrm{a}$ & $8.8 \mathrm{ab}$ & $8.4 a$ & $9.8 \mathrm{~b}$ & $10.3 \mathrm{ab}$ \\
\hline $300 / 0$ & $8.7 b c$ & $8.8 \mathrm{a}$ & $8.8 \mathrm{a}$ & $8.8 \mathrm{a}$ & $10.4 \mathrm{a}$ & $11.0 \mathrm{a}$ \\
\hline
\end{tabular}

'Values are the content of fly ash and manure in each mixture $\left(\mathrm{g} \mathrm{kg}^{-1}\right)$.

The balance of the mixture is Tivoli fine sand.
Kansas State University Beef Cattle Research Unit in Manhattan, Kansas. The fly ash was collected directly from the electrostatic precipitators to avoid complications related to the weathering of fly ash that occurs when it is stored outside.

Various mixtures of Tivoli fine sand, fly ash, and manure were used in the experiments. These mixtures are abbreviated as $X / Y$ where $X$ is the flyash content $\left(\mathrm{g} \mathrm{kg}^{-1}\right)$ of the mixture and $Y$ is the manure content $\left(\mathrm{g} \mathrm{kg}^{-1}\right)$ of the mixture. The balance of the mixture was Tivoli fine sand.

\section{Incubation and Germination:}

Fifteen mixtures of Tivoli fine sand, fly ash, and cattle manure were prepared for the incubation study (Table 1). Three replications were used. Three hundred grams of each mixture was prepared using air-dried materials. After mixing, water was added to bring the gravimetric water content to $200 \mathrm{~g} \mathrm{~kg}^{-1}$. The mixtures were mixed again and then stored in sealed plastic containers. Seventy-five grams of soil were taken from the containers at 3 , 10 and 30 days. A saturated paste was made with each sample. The $\mathrm{pH}$ of the paste was determined prior to vacuum filtration and the electrical conductivity (EC) of the filtrate was determined to assess salinity hazard (Rhoades 1996). A similar analysis was performed on the Tivoli fine sand, manure and fly ash.

Eleven combinations of Tivoli fine sand, fly ash, and cattle manure were used to test the germination of 10 plant species represented by 1 variety per species. Each germination test was replicated 3 times. 
Nine of the mixtures were also used in the incubation study and 2 additional mixtures not evaluated in the incubation study were also included: Unamended Tivoli fine sand (0/0) and a 200/200 mixture. The plant species were forage sorghum (variety Canex, Sorghum bicolor (L.) Moench), alkali sakaton (native, Sporobolus airoides (Torr.) Torr.), blue grama (native, Bouteloua gracilis (H.B.K.) Lag. ex Griffiths), sidesoats grama (variety El Reno, Bouteloua curtipendula (Michx.) Torr.), indiangrass (variety Cheyenne, Sorghastrum nutans (L.) Nash), switchgrass (variety Blackwell, Panicum virgatum L.), little bluestem (variety Cimarron, Andropogon scoparius Michx.), sand lovegrass (variety Bend, Eragrostis trichodes (Nutt.) Wood), sand sagebrush (native, Artemisia filifolia Torr.) and sand bluestem (variety Woodward, Andropogon hallii Hack.). The number of seeds used for each species was adjusted to expect 50 live seed for each test based on the germination test results included with the seed tags. Soil mixtures were prepared and incubated at $200 \mathrm{~g} \mathrm{~kg}^{-1}$ soil moisture content for 7 to 10 days prior to starting the germination trials. Each germination test used 60 grams of the soil/water mixture in a plastic petri dish. To prepare each test, 50 grams of the soil mixture was spread in the base of the petri dish. Pre-counted seed was spread on top of the soil and the seed was covered with an additional 10 grams of the soil mixture. If the soil mixture seemed too dry, additional water was added prior to sealing the petri dishes with parafilm. Petri dishes were incubated in a growth chamber set for 16 hours light and 8 hours dark. The day temperature was $30^{\circ} \mathrm{C}$ and the night temperature $20^{\circ} \mathrm{C}$. The number of germinated seedlings was scored every 2 or 3 days. Germinated seedlings were removed and discarded as they were counted.

\section{Greenhouse:}

Based on the results of the incubation and germination studies, 6 sand/fly ash/manure mixtures and 5 plant species were selected for the greenhouse study, located at $39.2^{\circ} \mathrm{N}$ latitude and $96.6^{\circ} \mathrm{W}$ longitude (Table 3 ). The experimental design was a factorial arrangement of plant species and mixture $(5 \times 6)$ with 4 replications for a total of 120 pots. A quantity of each mixture large enough to fill 20 pots ( 5 plant species and 4 replications) was prepared by mixing the appropriate amount of Tivoli fine sand, fly ash, and manure followed by deionized water to bring the gravimetric water content to
$200 \mathrm{~g} \mathrm{~kg}^{-1}$. Small samples of each mixture were taken and submitted to the Kansas State University Soil Testing Laboratory for the determination of saturated paste $\mathrm{EC}$ and $\mathrm{pH}$, salinity hazard, alkalinity hazard, and extractable $\mathrm{NO}_{3}+\mathrm{NH}_{4}$ using $1 \mathrm{M}$ $\mathrm{KCl}$ (Mulvaney 1996), $\mathrm{P}$ using $0.5 \mathrm{M}$ $\mathrm{NaHCO}_{3}$ (Kuo 1996) and potassium (K) using $1 M \mathrm{NH}_{4} \mathrm{OAc}$ (Helmke and Sparks 1996).

The equivalent of $2 \mathrm{~kg}$ of dry mixture was placed in each pot, which were lined with plastic to prevent drainage. The pots were covered with plastic and incubated for 1 week before seeding. An equal volume of seed was added to each pot and covered with approximately $7 \mathrm{~mm}$ of soil. Pots were thinned to a uniform number of plants per pot after germination. The pots were weighed approximately once per week and brought to a uniform $100 \mathrm{~g} \mathrm{~kg}^{-1}$ water content. Equal volumes of water were added to each pot as needed between weighings. Supplemental lighting was provided for 16 hours each day. Due to uneven germination among the treatments the emerged plants were destroyed 28 days after seeding and the trial was reseeded using larger quantities of seed. Acceptable numbers of plants were obtained in most pots after the second seeding. After 50 days of seedling growth each pot was scored for plant height and visual ratings of plant vigor and leaf tip burn. Plant vigor was rated on a 1 to 5 scale with 1 representing very poor growth and 5 representing vigorous plant growth. Leaf tip burn was scored on a 1 to 5 scale with 1 representing severe leaf burning and dieback and 5 representing no leaf burning. Leaf tip burn was evaluated as a symptom of plant stress from salinity.

Prior to harvest, visual observations of plant health and numbers were made. The pots were harvested 62 days after seeding by cutting the plants at the soil surface. Plant samples were rinsed with deionized water to remove dust, dried at $50^{\circ} \mathrm{C}$, and weighed. Soil samples were collected from each pot for determination of $\mathrm{pH}$, salinity, and extractable $\mathrm{N}, \mathrm{P}$, and $\mathrm{K}$ as described previously.

\section{Available Water Capacity:}

Available water capacity is best determined by using in situ field methods to measure field capacity and the permanent wilting point (Cassel and Nielsen 1986). Because these methods are prohibitively expensive and time-consuming, a common alternative is to estimate available water capacity with water retention measurements in the laboratory (Cassel and
Nielsen 1986). We used water retention measurements at $-1.5 \mathrm{MPa}$ to estimate the permanent wilting point and at $-10 \mathrm{kPa}$ and $-33 \mathrm{kPa}$ to estimate field capacity.

Bulk quantities of Tivoli sand, fly ash, and cattle manure were air-dried, sieved ( 2 $\mathrm{mm}$ ), and then combined in various amounts (dry-weight basis) to create 6 mixtures of soil material (Table 6). A subsample of each mixture was brought to an optimum water content for packing by adding $0.005 \mathrm{M} \mathrm{CaSO}_{4}$ solution. Subsamples were then mixed and allowed to equilibrate for several days.

Water retention measurements were made in pressure-plate extractors (Soilmoisture Equipment Corp., Santa Barabara, Calif.) using 100-kPa (10-, 33$\mathrm{kPa}$ measurements) and 1.5-MPa (1.5$\mathrm{MPa}$ measurements) porous ceramic plates. Retaining rings (5- $\mathrm{cm}$ diameter) were used to contain the samples on the plates. Samples were packed to a height of approximately $2.5 \mathrm{~cm}$ for $10-\mathrm{kPa}$ and $33-$ $\mathrm{kPa}$ measurements and a height of approximately $1 \mathrm{~cm}$ for 1.5 -MPa measurements.

Bulk density can have a small but measurable effect on water holding capacity at water potentials between 0 and $-100 \mathrm{kPa}$ (Klute 1986). Therefore, all mixtures of soil material were packed to a bulk density of $\rho_{b}=1.3 \mathrm{Mg} \mathrm{m}^{-3}$ for the $10-\mathrm{kPa}$ and 33$\mathrm{kPa}$ measurements. Bulk density was not controlled when packing samples for the 1.5-MPa measurements.

Saturation was achieved by immersing the plates and samples in $0.005 \mathrm{M} \mathrm{CaSO}_{4}$ solution for 24 hours prior to pressurization. Equilibration times of 3,5 , and 7 days were used for $10-\mathrm{kPa}, 33-\mathrm{kPa}$, and 1.5-MPa measurements, respectively. A bulk density of $\rho_{b}=1.3 \mathrm{Mg} \mathrm{m}^{-3}$ was assumed for all samples in order to express the results in terms of volumetric water content $\left(\theta_{\mathrm{v}}, \mathrm{m}^{3} \mathrm{~m}^{-3}\right)$. Each measurement was replicated 4 times.

Two approaches were used to calculate available water capacity, one generally applicable for coarse-textured soils and the other applicable for medium-textured soils. Water retention at $-10 \mathrm{kPa}$ was used to estimate field capacity in the coarsetextured approach, while water retention at $-33 \mathrm{kPa}$ was used in the medium-textured approach. Available water capacity was calculated using

$$
A W C_{c}=\left.\theta_{v}\right|_{-10 \mathrm{kPa}}-\left.\theta_{v}\right|_{-1.5 \mathrm{MPa}}
$$

$$
A W C_{m}=\left.\theta_{v}\right|_{-33 \mathrm{kPa}}-\left.\theta_{v}\right|_{-1.5 \mathrm{MPa}}
$$


where $A W C_{c}$ and $A_{W W C}$ are the estimates of available water capacity for coarse-textured and medium-textured approaches, respectively.

\section{Results and Discussion}

\section{Incubation and Germination:}

The saturated paste $\mathrm{pH}$ values for the Tivoli fine sand, fly ash, and manure were $8.2,9.8$, and 7.6, respectively. Saturated paste or 1:1 solid:water $\mathrm{pH}$ values for fly ash have been reported to be as high as 12.0 (McCarty et al. 1994). The EC of the saturated paste extracts for the Tivoli fine sand, fly ash and manure were 0.2, 15.4, and $4.5 \mathrm{dS} \mathrm{m}^{-1}$, respectively. The data indicate that the $\mathrm{pH}$ of the un-amended Tivoli fine sand is already high, and that fly ash has the potential for increasing soil $\mathrm{pH}$ even further. Similarly, both fly ash and manure have the potential to increase salinity when mixed with Tivoli fine sand.

Saturated paste $\mathrm{pH}$ and conductivities of the saturated paste extracts for all mixtures and sampling times in the incubation study are given in Table 1. The addition of manure to the Tivoli sand without fly ash decreased $\mathrm{pH}$ to approximately 7.7 at 3 days, while the addition of $100 \mathrm{~g} \mathrm{~kg}^{-1}$ or more of fly ash increased $\mathrm{pH}$ to 8.5 or higher regardless of manure additions. Saturated paste $\mathrm{pH}$ values did not continue to increase as the proportion of fly ash increased, reaching a maximum of 8.9 with the 200/0 mixture. Generally, saturated paste $\mathrm{pH}$ remained relatively constant over time for mixtures having fly ash or more fly ash than manure, and slightly decreased with time for mixtures having just manure or $\geq 200 \mathrm{~g} \mathrm{~kg}^{-1}$ manure. The decomposition of manure can produce organic acids that depress soil pH. The fly ash likely contains alkaline earth oxides and $\mathrm{CaCO}_{3}$, which would increase $\mathrm{pH}$ upon hydration (El-Magazi et al. 1988). A high soil $\mathrm{pH}$ can be detrimental to plant growth because of poor plant nutrient availability and salinity problems.

Saturated paste EC values were increased by the application of manure alone, to a value of $2.5 \mathrm{dS} \mathrm{m}^{-1}$ with the $0 / 300$ mixture at $t=3 \mathrm{~d}$ (Table 1 ). Application of even $50 \mathrm{~g} \mathrm{~kg}^{-1}$ fly ash increased EC values to 4.1 when combined with $50 \mathrm{~g} \mathrm{~kg}^{-1}$ manure (50/50 mixture), and to $7.0 \mathrm{dS} \mathrm{m}^{-1}$ when combined with $250 \mathrm{~g} \mathrm{~kg}^{-1}$ manure (50/250 mixture) at $t=3 \mathrm{~d}$. Further increases in the proportion of fly ash produced smaller increases in salinity, but the magnitude of the increase was much less than when com- paring $0 \mathrm{~g} \mathrm{~kg}^{-1}$ fly ash to $50 \mathrm{~g} \mathrm{~kg}^{-1}$ fly ash. Saturated paste EC values of $2.0 \mathrm{dS} \mathrm{m}^{-1}$ can be detrimental to plants that are sensitive to salinity, with tolerant species able to withstand EC values as high as 8.0 (Havlin et al. 1999). The data indicate that salt tolerant species may be necessary with as little as $50 \mathrm{~g} \mathrm{~kg}^{-1}$ fly ash in the mixture. The data also suggest that increasing the proportion of fly ash beyond $50 \mathrm{~g} \mathrm{~kg}^{-1}$ does not produce proportionately larger increases in salinity hazard. This suggests that higher proportions of fly ash could be used without further increasing salt affects on plants. However, high proportions of fly ash would increase the total salt load in the soil and without appropriate irrigation and drainage, chronic salinity problems may develop.

The saturated paste EC values consistently increased with time with both manure and fly ash amended mixtures (Table 1). This may be the result of sparingly soluble compounds dissolving slowly with time and their contribution to EC upon extraction. Jackson and Miller (2000) noted increases in soil solution $\mathrm{Ca}$, $\mathrm{Mg}, \mathrm{Na}$ and $\mathrm{K}$ concentrations from 3 to 33 days in an incubation study utilizing a Cecil sandy loam soil amended with fly ash. At the same time $\mathrm{pH}$ decreased, and the authors attributed the higher cation concentrations to a decrease in $\mathrm{pH}$ dependent cation exchange capacity. In the present study, $\mathrm{pH}$ remained relatively constant for mixtures that contained only fly ash while EC values increased, and the mechanism proposed by Jackson and Miller (2000) does not appear to be a factor.

Ten species each represented by 1 variety were tested in the germination trials, 9 of which are presented (Table 2). The germination patterns observed varied with the species, so species were examined separately (Table 2). Sand sage was the only non-grass species tested as it is a common colonizer on the Tivoli sands. The source of seed used apparently had low viability under the conditions of our trial; only 1 seed germinated in all treatments so this species will not be discussed further.

Two species, alkali sacaton and 'Canex' forage sorghum had high germination rates in all treatments. These species would be acceptable components for further trials with any of the soil mixtures. Based on seed germination results, they may be able to tolerate greater percentages of fly ash and cattle manure. For 2 treatments with alkali sacaton there were more than 50 seedlings counted. This suggests that the germination data received with the seed was incorrect and that greater than 50 live seeds were planted.
The results for the other species vary. In general, germination percentages were lower than alkali sacaton and the forage sorghum, but acceptable numbers of plants germinated for many soil mixtures with only a few exceptions (Table 2). Sideoats grama, for example, showed a stable number of seedlings across all soil mixtures. Some species may be showing the effects of increasing percentages of manure, fly ash or the combination. Other species had variable germination results, with no clear pattern.

Sand lovegrass appeared to show the most sensitivity to increased fly ash. Seedling numbers were high for zero percent fly ash with any percentage of manure. Any amount of fly ash appeared to depress seedling numbers. When $100 \mathrm{~g}$ $\mathrm{kg}^{-1}$ fly ash included increasing amounts of manure, the manure appeared to alleviate the effects of the fly ash. The 250/50 treatment had the lowest germination. Switchgrass showed a similar pattern to sand lovegrass although the results were somewhat more variable. The $250 / 50 \mathrm{mix}-$ ture also had low germination and 200 to $250 \mathrm{~g} \mathrm{~kg}^{-1}$ fly ash may be approaching the limit for switchgrass.

Results for indiangrass were quite variable, but there may be a trend toward lower germination with increase percentages of fly ash, manure or both. Germination for the 200/200 and 250/50 mixtures was low.

Blue grama showed the most clear benefit of increasing manure percentage with no fly ash or $100 \mathrm{~g} \mathrm{~kg}^{-1}$ fly ash, but germination was more stable at $200 \mathrm{~g} \mathrm{~kg}^{-1}$ and $250 \mathrm{~g} \mathrm{~kg}^{-1} \mathrm{fly}$ ash. Seedling numbers were acceptable for these soil mixtures.

Little bluestem and sand bluestem had variable results although both species may benefit from added manure. For these species, mixtures without manure or the $250 / 50$ mixture had the lowest numbers of seedlings.

\section{Greenhouse:}

The salinity and alkalinity hazards of the mixtures and the plant available $\mathrm{N}, \mathrm{P}$, and $\mathrm{K}$ contents of the mixtures were determined (Table 3). Similar to the results of the incubation study, the addition of fly ash increased saturated paste EC to 8 to 10 $\mathrm{dS} \mathrm{m}^{-1}$, giving salinity hazards from high to excessive. The alkalinity hazards were low, indicating that soil physical problems associated with excess sodium $(\mathrm{Na})$ will not be a concern. The addition of fly ash slightly increased extractable $\mathrm{N}, \mathrm{P}$, and $\mathrm{K}$ concentrations while the addition of manure greatly increased extractable plant nutrient concentrations. The addition of 
Table 2. Mean number of germinated seedlings for each combination of plant species and mixtures. The equivalent of 50 live seed were planted for each specie.

\begin{tabular}{|c|c|c|c|c|c|c|c|c|c|}
\hline & $\begin{array}{c}\text { Alkali } \\
\text { Sacaton }\end{array}$ & $\begin{array}{c}\text { Blue } \\
\text { Grama }\end{array}$ & $\begin{array}{c}\text { Forage } \\
\text { Sorghum }\end{array}$ & Indiangrass & $\begin{array}{c}\text { Little } \\
\text { Bluestem }\end{array}$ & $\begin{array}{c}\text { Sand } \\
\text { Bluestem }\end{array}$ & $\begin{array}{c}\text { Sideoats } \\
\text { Grama }\end{array}$ & $\begin{array}{c}\text { Sand } \\
\text { lovegrass }\end{array}$ & $\begin{array}{l}\text { Switch- } \\
\text { grass }\end{array}$ \\
\hline $0 / 0^{1}$ & 44.3 & 5.7 & 38.0 & 15.0 & $\begin{array}{c}--(\mathrm{No})-- \\
8.0\end{array}$ & 10.3 & 24.7 & 31.0 & 23.7 \\
\hline $0 / 100$ & 42.0 & 23.0 & 48.7 & 17.0 & 13.3 & 16.7 & 30.0 & 40.0 & 20.7 \\
\hline $100 / 0$ & 43.7 & 3.3 & 43.0 & 12.3 & 10.3 & 7.0 & 24.3 & 10.7 & 12.7 \\
\hline $50 / 150$ & 63.7 & 10.3 & 44.7 & 11.0 & 17.0 & 8.7 & 29.3 & 10.0 & 6.0 \\
\hline $100 / 100$ & 59.7 & 19.0 & 45.7 & 9.3 & 11.7 & 12.0 & 25.3 & 24.3 & 11.0 \\
\hline $200 / 0$ & 43.0 & 23.0 & 44.7 & 11.0 & 9.0 & 14.3 & 30.3 & 11.7 & 10.7 \\
\hline $0 / 300$ & 44.0 & 32.0 & 47.3 & 8.7 & 12.7 & 11.0 & 30.7 & 39.0 & 17.3 \\
\hline $100 / 200$ & 48.7 & 22.3 & 47.0 & 11.0 & 11.7 & 13.7 & 38.7 & 38.0 & 15.7 \\
\hline $200 / 100$ & 40.3 & 15.7 & 48.0 & 7.7 & 12.7 & 9.3 & 26.0 & 16.3 & 2.0 \\
\hline $250 / 50$ & 39.3 & 14.3 & 44.7 & 4.3 & 7.3 & 7.3 & 27.7 & 3.7 & 3.0 \\
\hline $200 / 200$ & 46.0 & 18.3 & 43.7 & 2.7 & 12.7 & 10.7 & 28.3 & 18.7 & 11.7 \\
\hline
\end{tabular}

Values are the content of fly ash and manure in each mixture $\left(\mathrm{g} \mathrm{kg}^{-1}\right)$. The balance of the mixture is Tivoli fine sand.

some manure is necessary to supply plant nutrients. The addition of manure may overcome the $P$ fixing limitations described by Gray and Schwab (1992).

Germination was delayed in the greenhouse as compared to the germination trials, which was likely because of the variable soil moisture conditions under greenhouse conditions. Germination occurred first with the $0 / 0$ mixture and generally within 1 week of seeding.

Each characteristic described the status of plant health and performance after 50 days of growth. Plant health and performance data are given in Tables 4 and 5 . With the exception of alkali sacaton, all species showed a decrease in vigor rating when comparing mixtures with fly ash to the $0 / 0$ mixture (Table 4 ). Further, sideoats grama and forage sorghum generally had significantly lower vigor ratings for mixtures containing 200 or $300 \mathrm{~g} \mathrm{~kg}^{-1}$ fly ash as compared to $100 \mathrm{~g} \mathrm{~kg}^{-1}$ fly ash. Leaf tip burn ratings were not influenced by mixture for alkali sacaton and forage sorghum. However, leaf tip burn ratings for forage sorghum in the $0 / 0$ mixture were $<5$, indicating some symptoms even under low salinity conditions. For the remaining species, leaf tip burn ratings decreased (symptoms increased) when fly ash was present in the mixture as compared to the $0 / 0$ mixture.

Plant height was very sensitive to mixture composition. Across all plant species, height decreased a minimum of $19 \%$ when comparing the $0 / 0$ mixture to those containing fly ash (Table 5). Biomass was generally lower in mixtures containing fly ash compared to the $0 / 0$ mixture for all species except alkali sacaton. For alkali sacaton, the 200/100,200/200, and $100 / 100$ mixtures had biomass that was not significantly different than $0 / 0$, while the 200/0 and 300/100 mixtures were significantly lower. Thus, for biomass, alkali sacaton can tolerate $200 \mathrm{~g} \mathrm{~kg}^{-1}$ of fly ash in the mixture provided that manure was also present at $\geq 100 \mathrm{~g} \mathrm{~kg}^{-1}$.

For all species the best plant growth was obtained in the unamended Tivoli sand treatment. Any amount of fly ash, from 100 to $300 \mathrm{~g} \mathrm{~kg}^{-1}$, depressed plant growth. The performance on fly ash, however, varied among species. Alkali sacaton is known to be a highly salt tolerant grass (Salo et al. 1999). Although it grew best in $100 \%$ sand, it appeared quite healthy in all treatments with no leaf burning and only a small depression in plant height in the other soil treatments. Growth of alkali sacaton was sufficient in all treatments to suggest that it would perform well in the field. All other species performed very well in the $0 / 0$ mixture and showed substantial reductions in growth and increased leaf burning symptoms in all other soil treatments. The 200/200 mixture showed consistently better performance than the other treatments containing fly ash. This indicated that cattle manure present at 200 $\mathrm{g} \mathrm{kg}^{-1}$ or greater could be helpful in ameliorating the undesirable effects of fly ash.
Although plants survived in all of the treatments, there may not be sufficient growth of the other native perennial grasses besides alkali sacaton to suggest that they would be able to survive the winter. Forage sorghum had relatively poor growth on fly ash-amended soils, but it may serve some useful functions as a cover crop to gradually improve the soil conditions.

Mulhern et al. (1989) studied field establishment and survival of vegetation for 3 years on fly ash deposits from a coalfired plant in eastern Kansas. Treatments with added fertilizer and cattle manure resulted in the best vegetation cover of herbaceous vegetation. Salo et al. (1999) studied field establishment of salt tolerant plant species on sediments from a saline flue gas desulfurization pond in Arizona. Species that performed well in greenhouse trials were more difficult to establish under field conditions. Manure additions helped establishment and survival. Pilot field tests are needed to test establishment and survival of species under field conditions. Adequate moisture is needed to

Table 3. Selected soil chemical properties for the 6 mixtures used in the greenhouse and soil physical properties studies.

\begin{tabular}{|c|c|c|c|c|c|c|c|}
\hline \multirow[b]{2}{*}{ Mixture } & \multicolumn{4}{|c|}{ 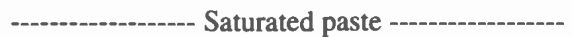 } & \multicolumn{3}{|c|}{----------- Extractable ---------. } \\
\hline & EC & $\mathrm{pH}$ & $\begin{array}{l}\text { Salinity } \\
\text { hazard }\end{array}$ & $\begin{array}{c}\text { Alkalinity } \\
\text { hazard }\end{array}$ & $\mathrm{N}^{3}$ & $\mathrm{P}^{4}$ & $\mathrm{~K}^{3}$ \\
\hline & $\left(\mathrm{dS} \mathrm{m}^{-1}\right)$ & & & & $\overline{-------}$ & (mg k & $-\ldots$ \\
\hline $0 / 0^{1}$ & 0.7 & 6.9 & $\mathrm{~L}^{2}$ & L & 8 & 14 & 61 \\
\hline $200 / 0$ & 7.6 & 7.8 & $\mathbf{H}$ & L & 25 & 35 & 98 \\
\hline $200 / 100$ & 8.9 & 8.4 & E & L & 58 & 330 & 699 \\
\hline $200 / 200$ & 9.4 & 8.6 & E & L & 82 & 500 & 1293 \\
\hline $100 / 100$ & 6.7 & 8.6 & $\mathrm{H}$ & $\mathrm{L}$ & 29 & 350 & 653 \\
\hline $300 / 100$ & 10.4 & 8.9 & E & L & 24 & 400 & 782 \\
\hline
\end{tabular}

Values are the content of fly ash and manure in each mixture $\left(\mathrm{g} \mathrm{kg}^{-1}\right)$. The balance of the mixture is Tivoli fine sand. ${ }^{2} \mathrm{~L}=$ low $\left(\mathrm{EC}<1.9 \mathrm{dS} \mathrm{m}^{-1}\right.$, exchangeable $\mathrm{Na}$ percentage $\left.<10 \%\right), \mathrm{H}=\mathrm{high}\left(\mathrm{EC}>3.9\right.$ and $<8.9 \mathrm{dS} \mathrm{m}^{-1}, \mathrm{E}=$ excessive $(\mathrm{EC}>$ $8.9 \mathrm{dS} \mathrm{m}^{-1}$ )

${ }_{4}^{3} \mathrm{NO}_{3}-\mathrm{N}+\mathrm{NH}_{4}-\mathrm{N}, 1 M \mathrm{KCl}$ extractable

${ }_{5}^{4}$ Olsen's exctractable $\left(0.5 \mathrm{M} \mathrm{NaHCO}_{3}\right)$
$1 \mathrm{M} \mathrm{NH} \mathrm{NAAc}_{4} \mathrm{OAtractable}$ 
Table 4. Vigor and leaf tip burn ratings for 5 plant species used in the greenhouse study. Vigor and leaf tip burn were visually assessed on a scale of 1 to 5 , with 5 representing high vigor or no burn. Means within a column with the same letter are not statistically different by LSD at $P \leq 0.05$.

\begin{tabular}{|c|c|c|c|c|c|c|c|c|c|c|}
\hline Mixture & $\begin{array}{c}\text { Alkali } \\
\text { Sacaton }\end{array}$ & $\begin{array}{c}\text { Blue } \\
\text { Grama }\end{array}$ & $\begin{array}{l}\text { Forage } \\
\text { Sorghum }\end{array}$ & $\begin{array}{c}\text { Sand } \\
\text { Bluestem }\end{array}$ & $\begin{array}{c}\text { Sideoats } \\
\text { Grama }\end{array}$ & $\begin{array}{l}\text { Alkali } \\
\text { Sacaton }\end{array}$ & $\begin{array}{c}\text { Blue } \\
\text { Grama }\end{array}$ & $\begin{array}{l}\text { Leaf tip burn } \\
\text { Forage } \\
\text { Sorghum }\end{array}$ & $\begin{array}{c}\text { Sand } \\
\text { Bluestem }\end{array}$ & $\begin{array}{c}\text { Sideoats } \\
\text { Grama }\end{array}$ \\
\hline $0 / 0^{1}$ & $4.8 \mathrm{a}$ & $5.0 \mathrm{a}$ & $4.0 \mathrm{a}$ & $4.8 \mathrm{a}$ & $5.0 \mathrm{a}$ & $5.0 \mathrm{a}$ & $5.0 \mathrm{a}$ & $3.0 \mathrm{a}$ & $4.8 \mathrm{a}$ & $4.5 a$ \\
\hline $200 / 0$ & $3.8 \mathrm{a}$ & $1.3 \mathrm{~b}$ & $2.0 \mathrm{c}$ & $1.8 \mathrm{~b}$ & $1.0 \mathrm{c}$ & $5.0 \mathrm{a}$ & $1.5 \mathrm{c}$ & $3.0 \mathrm{a}$ & $2.3 b$ & $1.0 \mathrm{~d}$ \\
\hline $200 / 100$ & $4.0 \mathrm{a}$ & $1.5 \mathrm{~b}$ & $2.0 \mathrm{c}$ & $1.5 \mathrm{~b}$ & $2.0 \mathrm{bc}$ & $5.0 \mathrm{a}$ & $2.3 c$ & $3.3 \mathrm{a}$ & $3.0 \mathrm{~b}$ & $2.5 c$ \\
\hline $200 / 200$ & $4.3 \mathrm{a}$ & $2.8 \mathrm{~b}$ & $2.0 \mathrm{c}$ & $1.5 \mathrm{~b}$ & $2.0 \mathrm{bc}$ & $5.0 \mathrm{a}$ & $3.5 b c$ & $3.5 \mathrm{a}$ & $3.3 b$ & $2.0 \mathrm{~cd}$ \\
\hline $100 / 100$ & $4.3 \mathrm{a}$ & $2.5 b$ & $3.0 \mathrm{~b}$ & $2.5 b$ & $3.3 b$ & $5.0 \mathrm{a}$ & $3.8 \mathrm{~b}$ & $3.3 \mathrm{a}$ & $3.3 \mathrm{~b}$ & $3.5 b c$ \\
\hline $300 / 100$ & $4.3 \mathrm{a}$ & $1.3 b$ & $1.8 \mathrm{c}$ & $1.3 b$ & $1.5 \mathrm{a}$ & $5.0 \mathrm{a}$ & $2.5 \mathrm{c}$ & $2.8 \mathrm{a}$ & $2.3 b$ & $1.8 \mathrm{~cd}$ \\
\hline
\end{tabular}

Values are the content of fly ash and manure in each mixture $\left(\mathrm{g} \mathrm{kg}^{-1}\right)$. The balance of the mixture is Tivoli fine sand.

ensure good germination. Under the limited and variable precipitation conditions in Garden City, Kans., irrigation may be needed to ensure vegetation establishment.

\section{Available Water Capacity:}

Volumetric water content data for each mixture and water potential are summarized in Table 6 . The small standard errors (Table 6) indicate that the methods employed for the water retention measurements provided excellent precision. Note, however, that the magnitude of the standard error varied with water potential. The standard errors were $0.010,0.006$, and 0.002 for the $10 \mathrm{kPa}, 33 \mathrm{kPa}$, and $1.5 \mathrm{MPa}$ water contents, respectively. Greater variability at higher water potentials is most likely due to the fact that pore geometry has a much greater influence on water retention at higher water potentials. Although samples were packed to the same bulk density, the packing procedure will not yield samples of identical pore geometry.

The addition of amendments caused significant changes in the water retention properties of the Tivoli fine sand (Table 6). Adding fly ash or cattle manure significantly increased water retention at all 3 water potentials, and the treatment effect (mixture) was consistent across all 3 water potentials. The differences in water retention appear to be directly related to the total fraction of amendments in each mix- ture, but it was not possible to distinguish differences between the effects of fly ash and cattle manure. Mixtures 200/200 and $300 / 100$ consisted of $600 \mathrm{~g} \mathrm{~kg}^{-1}$ sand and different amounts of fly ash and manure. Comparison of the mean water contents for mixtures $200 / 200$ and 300/100 shows no significant differences in water retention. Similarly, Mixtures $200 / 0$ and $100 / 100$, both with $800 \mathrm{~g} \mathrm{~kg}^{-1}$ sand and different amounts of fly ash and manure, did not show a significant difference in water retention at the $10 \mathrm{kPa}$ potential. Mixtures 200/0 and 100/100 showed only slight differences at the $10 \mathrm{kPa}$ and 1.5 $\mathrm{kPa}$ water potentials. Thus, fly ash and cattle manure appear to have a similar affect on the water retention characteristics of Tivoli sand.

The differences in water retention translated into significant differences in available water capacity (Table 6). Notice that the mixture effects are identical to those observed for the water retention measurements. The differences in available water capacity appear to be directly related to the total fraction of amendments. We note, however, that treatment comparisons are complicated by the fact that the best estimate of available water capacity may vary with mixture. For instance, $\mathrm{AWC}_{\mathrm{c}}$ is probably the best estimate of available water capacity for mixture $0 / 0$, but $A W C_{m}$ may be the best estimate of available water capacity for mixture 200/200 because it displays water retention characteristics similar to that of a medium-textured soils. Without in situ field measurements of field capacity, we can only speculate which estimate of the available water capacity is best for mixtures containing fly ash. A conservative approach for making treatment comparisons would be to use $\mathrm{AWC}_{\mathrm{c}}$ for $0 / 0$ and $\mathrm{AWC}_{\mathrm{m}}$ for the remaining mixtures.

Available water capacity can also be expressed on a depth basis when the depth of the rooting zone is known. By assuming that rooting depth is equivalent to cover thickness, available water capacity on a depth basis can be obtained by multiplying $\mathrm{AWC}_{\mathrm{c}}$ and $\mathrm{AWC}_{\mathrm{m}}$ by cover thickness (Table 7). For example, $\mathrm{AWC}_{\mathrm{c}}=0.095$ $\mathrm{cm}^{3} \mathrm{~cm}^{-3}$ for $0 / 0$ (Table 6). Multiplying this by $30 \mathrm{~cm}$ gives $\mathrm{AWC}_{\mathrm{c}}=2.9 \mathrm{~cm}$ for a $30-\mathrm{cm}$ cover.'Similarly, multiplying by 45 $\mathrm{cm}$ gives $\mathrm{AWC}_{\mathrm{c}}=4.3 \mathrm{~cm}$ for a $45-\mathrm{cm}$ cover. Treatment comparisons in Table 7 are also complicated by the fact that the best estimate of available water capacity may vary with mixture. As suggested earlier, a conservative approach for making treatment comparisons would be to use $A W C_{c}$ for $0 / 0$ and $A W C_{m}$ for the remaining mixtures. Even with this conservative approach, it is clear that the amendments have a substantial effect on available water capacity. For all cover depths, available water capacity is doubled or nearly doubled for $200 / 100,200 / 200$, and

Table 5. Height and biomass for 5 plant species used in the greenhouse study. Means within a column with the same letter are not statistically different by $\mathrm{LSD}$ at $\mathbf{P} \leq \mathbf{0 . 0 5}$.

\begin{tabular}{|c|c|c|c|c|c|c|c|c|c|c|}
\hline \multirow[b]{3}{*}{ Mixture } & \multicolumn{5}{|c|}{ Height } & \multicolumn{5}{|c|}{ Biomass } \\
\hline & Alkali & Blue & Forage & Sand & Sideoats & Alkali & Blue & Forage & Sand & Sideoats \\
\hline & Sacaton & Grama & Sorghum & Bluestem & Grama & Sacaton & Grama & Sorghum & Bluestem & Grama \\
\hline & \multicolumn{5}{|c|}{ 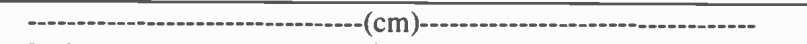 } & \multicolumn{5}{|c|}{ - } \\
\hline $0 / 0^{1}$ & $30.8 \mathrm{a}$ & $50.0 \mathrm{a}$ & $48.0 \mathrm{a}$ & $38.8 \mathrm{a}$ & $48.0 \mathrm{a}$ & $2.85 \mathrm{a}$ & $2.14 \mathrm{a}$ & $4.93 \mathrm{a}$ & $1.33 \mathrm{a}$ & $2.36 \mathrm{a}$ \\
\hline $200 / 0$ & $23.5 b c$ & $10.3 \mathrm{c}$ & $24.8 \mathrm{c}$ & $13.0 \mathrm{bc}$ & $17.5 \mathrm{c}$ & $1.55 \mathrm{~b}$ & $0.12 b$ & $0.93 c$ & $0.07 b$ & $0.22 \mathrm{~b}$ \\
\hline $200 / 100$ & $20.3 b c$ & $19.5 b$ & $22.5 c$ & $10.0 \mathrm{c}$ & $14.0 \mathrm{c}$ & $2.54 \mathrm{a}$ & $0.19 \mathrm{~b}$ & $1.32 \mathrm{c}$ & $0.07 b$ & $0.54 b$ \\
\hline $200 / 200$ & $24.8 b$ & $19.3 \mathrm{~b}$ & $36.5 b$ & $18.5 b$ & $26.5 b$ & $2.35 a$ & $0.26 \mathrm{~b}$ & $1.22 \mathrm{c}$ & $0.09 b$ & $0.56 b$ \\
\hline $100 / 100$ & $19.2 \mathrm{c}$ & $8.8 c$ & $24.8 c$ & $12.3 b c$ & $12.0 \mathrm{c}$ & $2.60 \mathrm{a}$ & $0.30 \mathrm{~b}$ & $2.66 \mathrm{~b}$ & $0.26 \mathrm{~b}$ & $0.66 \mathrm{~b}$ \\
\hline $300 / 100$ & $22.0 \mathrm{bc}$ & $7.3 \mathrm{c}$ & $22.3 c$ & $7.7 \mathrm{c}$ & $11.3 c$ & $1.36 \mathrm{~b}$ & $0.08 b$ & $0.87 \mathrm{c}$ & $0.54 \mathrm{ab}$ & $0.26 \mathrm{~b}$ \\
\hline
\end{tabular}

Values are the content of fly ash and manure in each mixture $\left(\mathrm{g} \mathrm{kg}^{-1}\right)$. The balance of the mixture is Tivoli fine sand. 
Table 6. Mean volumetric water content $\left(\theta_{\mathrm{v}}\right)$ at water potentials of $-10 \mathrm{kPa},-33 \mathrm{kPa}$, and -1.5 $\operatorname{MPa}(n=4)$, and available water capacity as computed from Eq. [1] $(\mathbf{A W C})$ and Eq. [2] $\left(A W C_{m}\right)$.

\begin{tabular}{|c|c|c|c|c|c|}
\hline \multirow[b]{2}{*}{ Mixture } & \multicolumn{3}{|c|}{ Water potential } & \multicolumn{2}{|c|}{ Available water capacity } \\
\hline & $-10 \mathrm{kPa}$ & $-33 \mathrm{kPa}$ & $-1.5 \mathrm{MPa}$ & $\mathrm{AWC}_{\mathrm{c}}$ & $\mathrm{AWC}_{\mathrm{m}}$ \\
\hline & & & $\left(\mathrm{m}^{3} \mathrm{~m}^{-3}\right)-$ & & \\
\hline $0 / 0^{1}$ & $0.130 \mathrm{~d}^{2}$ & $0.101 \mathrm{e}$ & $0.035 \mathrm{e}$ & $0.095 \mathrm{~d}$ & $0.066 \mathrm{~d}$ \\
\hline $200 / 0$ & $0.258 \mathrm{c}$ & $0.228 \mathrm{c}$ & $0.101 \mathrm{c}$ & $0.157 \mathrm{c}$ & $0.127 \mathrm{c}$ \\
\hline $200 / 100$ & $0.315 b$ & $0.277 b$ & $0.129 b$ & $0.186 \mathrm{~b}$ & $0.148 b$ \\
\hline $200 / 200$ & $0.382 a$ & $0.328 a$ & $0.157 \mathrm{a}$ & $0.225 a$ & $0.171 \mathrm{a}$ \\
\hline $100 / 100$ & $0.251 \mathrm{c}$ & $0.216 \mathrm{~d}$ & $0.095 \mathrm{~d}$ & $0.156 c$ & $0.121 \mathrm{c}$ \\
\hline $300 / 100$ & $0.368 \mathrm{a}$ & $0.333 a$ & $0.159 a$ & $0.209 a$ & 0.174 \\
\hline SE & 0.010 & 0.006 & 0.002 & $0.011^{3}$ & $0.006^{3}$ \\
\hline LSD & 0.016 & 0.009 & 0.003 & $0.022^{4}$ & $0.013^{4}$ \\
\hline
\end{tabular}

Values are the content of fly ash and manure in each mixture $\left(\mathrm{g} \mathrm{kg}^{-1}\right)$. The balance of the mixture is Tivoli fine sand.

${ }^{2}$ Values within a column followed by the same letter are not significantly different at the 0.05 probability level according to Fisher's least significant difference (LSD).

${ }^{3}$ Standard error (SE) for available water capacity was computed from the SE for the mean water content at each potential.

${ }^{4}$ Least significant difference (LSD) for available water capacity was computed using a conservative estimate for the degrees of freedom based on the variance for a single mean water content.

$300 / 100$, which contain 600 or $700 \mathrm{~g} \mathrm{~kg}^{-1}$ sand.

One purpose of this project was to determine if it is possible to reduce cover thickness to less than $60 \mathrm{~cm}$ and still be able to establish and sustain vegetative cover. The results in Table 7 clearly show that it is possible to reduce cover thickness to 45 $\mathrm{cm}$ without loss of available water capacity, if amendments are used. For example, we have $A W C_{c}=5.7 \mathrm{~cm}$ for a $60-\mathrm{cm}$ cover of mixture $0 / 0$. Using the conservative approach suggested above, the same available water capacity $\left(\mathrm{AWC}_{\mathrm{m}}=5.7\right.$ $\mathrm{cm}$ ) can be obtained with a $45-\mathrm{cm}$ cover of mixture 200/0. However, it does not appear possible to reduce cover thickness from $60 \mathrm{~cm}$ to $30 \mathrm{~cm}$ without loss of available water capacity. All mixtures containing fly ash have $A W C_{m}<5.7 \mathrm{~cm}$ for the 30-cm cover.

We concluded above that a $45-\mathrm{cm}$ cover of mixture 200/0 would have the same available water capacity $\left(\mathrm{AWC}_{\mathrm{m}}=5.7\right.$ $\mathrm{cm}$ ) as a $60-\mathrm{cm}$ cover of mixture $0 / 0$ $\left(A W C_{c}=5.7 \mathrm{~cm}\right)$. An even greater water

Table 7. Available water capacity on a depth basis for covers of thickness 30,45 , and $60 \mathrm{~cm}$. Values were obtained by multiplying values of $A W C_{c}$ and $A W C_{m}$ in Table 1 by the cover depth.

\begin{tabular}{|c|c|c|c|c|c|c|}
\hline \multirow[b]{3}{*}{ Mixture } & \multicolumn{6}{|c|}{ Cover depth } \\
\hline & \multicolumn{2}{|c|}{$30 \mathrm{~cm}$} & \multicolumn{2}{|c|}{$45 \mathrm{~cm}$} & \multicolumn{2}{|c|}{$60 \mathrm{~cm}$} \\
\hline & $\mathrm{AWC}_{\mathrm{c}}$ & $\mathrm{AWC}_{\mathrm{m}}$ & $\mathrm{AWC}_{\mathrm{c}}$ & $\overline{\mathrm{AWC}_{\mathrm{m}}}$ & $\overline{\mathrm{AWC}_{\mathrm{c}}}$ & $\mathrm{AWC}_{\mathrm{m}}$ \\
\hline $0 / 0^{1}$ & 2.9 & 2.0 & 4.3 & 3.0 & 5.7 & 4.0 \\
\hline $200 / 0$ & 4.7 & 3.8 & 7.1 & 5.7 & 9.4 & 7.6 \\
\hline $200 / 100$ & 5.6 & 4.4 & 8.4 & 6.7 & 11.2 & 8.9 \\
\hline $200 / 200$ & 6.8 & 5.1 & 10.1 & 7.7 & 13.5 & 10.3 \\
\hline $100 / 100$ & 4.7 & 3.6 & 7.0 & 5.4 & 9.4 & 7.3 \\
\hline $300 / 100$ & 6.3 & 5.2 & 9.4 & 7.8 & 12.5 & 10.4 \\
\hline
\end{tabular}

${ }^{1}$ Values are the content of fly ash and manure in each mixture $\left(\mathrm{g} \mathrm{kg}^{-1}\right)$. The balance of the mixture is Tivoli fine sand. ferent densities. Differences in bulk density may cause slight differences in the estimates of available water capacity reported herein.

\section{Summary and Conclusions}

The addition of small amounts of fly ash greatly increased the $\mathrm{pH}$ and salinity of the Tivoli sand, while the addition of manure increased salinity slightly and decreased $\mathrm{pH}$. Salinity played a major role in plant selection as only the salt tolerant alkali sacaton was able to grow relatively unaffected in mixtures containing fly ash. The study used fly ash taken directly from the electrostatic precipitators so the conditions studied likely represent a worst-case scenario for salts. Fly ash that has weathered would likely cause less of an increase in salinity upon addition to the Tivoli fine sand. However, the process of leaching soluble salts out of the fly ash would be slow under low rainfall conditions in this environment. Cattle manure adds much needed plant nutrients and provides additional soil physical benefits and should be considered essential in the mixtures.

Available water capacity was evaluated for 6 different mixtures of Tivoli fine sand, fly ash, and cattle manure. Available water capacity was approximated by measuring water retention characteristics at water potentials of $-10 \mathrm{kPa},-33 \mathrm{kPa}$, and $-1.5 \mathrm{MPa}$. Adding fly ash and/or cattle manure significantly increased water retention at all 3 water potentials and significantly increased available water capacity. The changes in water retention and available water capacity appear to be directly related to the total fraction of amendments in each mixture. Slight or no significant differences in water retention or available water capacity were observed for mixtures with the same amount of sand but different amounts of fly ash and manure.

Available water capacity was also calculated on a depth basis for hypothetical soil covers of varying thickness. Using a conservative approach, we predict that cover thickness could be reduced from $60 \mathrm{~cm}$ to $45,39,34,47$, or $33 \mathrm{~cm}$ for mixtures $200 / 0$, $200 / 100,200 / 200,100 / 100$ or $300 / 100$, respectively, while maintaining the same available water capacity. Other factors, such as reduced plant nutrient supply and the possibility of plant roots contacting underlying fly ash, may also need to be considered when reducing cover thickness. 


\section{Literature Cited}

Adriano, D.C. and J.T. Weber. 2001. Influence of fly ash on soil physical properties and turfgrass establishment. J. Environ. Qual. 30:596-601.

Adriano, D.C., A.L. Page, A.A. Elseewi, A.C. Chang, and I. Straughan. 1980. Utilization and disposal of fly ash and other coal residues in terrestrial ecosystems: A review. J. Environ. Qual. 9:333-344.

Campbell, D.J., W.E. Fox, R.L. Aitken, and L.C. Bell. 1983. Physical characteristics of sands amended with fly ash. Aust. J. Soil Res. 21:147-154.

Cassell, D. K. and D. R. Nielsen. 1986. Field capacity and available water capacity. p. 901-926. In A. Klute (ed.) Method of soil analysis. Part 1. 2nd ed. Agronomy Monograph 9. ASA and SSSA, Madison, Wisc.

Chang, A.C., J.L. Lund, A.L. Page, and J.E. Warneke. 1977. Physical properties of fly ash-amended soils. J. Environ. Qual. 6:267-270.

El-Magazi, D., D. J. Lisk, and L.H. Weinstein. 1988. A review of physical, chemical, and biological properties of fly ash and effects on agricultural ecosystems. Sci. Total Environ. 74:1-37.

Gangloff, W.J., M. Ghodrati, J.T. Sims, and B.L. Vasilas. 2000. Impact of fly ash amendment and incorporation method on hydraulic properties of a sandy soil. Water Air Soil Pollut. 119:23-245.

Ghodratti, M., J.T. Sims, and B.L. Vasilas. 1995. Evaluation of fly ash as a soil amendment for the Atlantic Coastal Plain: I. Soil hydraulic properties and elemental leaching. Water Air Soil Pollut. 81:349-361.
Gorman, J.M., J.C. Sencidiver, D.J. Horvath, R.N. Singh, and R.F. Keefer. 2000. Erodibility of fly ash used as a topsoil substitute in mineland reclamation. $J$. Environ. Qual. 29:805-811.

Gray, C.A. and A.P. Schwab. 1992. Phosphorus-fixing ability of high $\mathrm{pH}$, high calcium, coal-combustion waste materials. Water Air Soil Pollution 69:309-320.

Havlin, J.L., J.D. Beaton, S.L. Tisdale, and W.L. Nelson. 1999. Soil Fertility and Fertilizers: An Introduction to Nutrient Management, Sixth Edition. Prentice Hall, Upper Saddle River, N.J.

Helmke, P.A. and D.L. Sparks. 1996. Lithium, sodium, potassium, rubidium, and cesium. p. 551-574. In D.L. Sparks (ed.) Methods of Soil Analysis. Part 3. Chemical Methods. SSSA Book Ser. 5 SSSA and ASA, Madison, Wisc.

Jackson, B.P. and W.P. Miller. 2000. Soil solution chemistry of a fly ash-, poultry litter-, and sewage-sludge amended soil. J. Environ. Qual. 29:430-436.

Klute, A. 1986. Water retention: Laboratory methods. p. 635-662. In A. Klute (ed.) Method of soil analysis. Part 1. 2nd ed. Agronomy Monograph 9. ASA and SSSA, Madison, Wisc.

Kuo, S. 1996 Phosphorus. p. 869-920. In: D.L. Sparks (ed.) Methods of Soil Analysis. Part 3. Chemical Methods. SSSA Book Ser. 5 SSSA and ASA, Madison, Wisc.

Lehrsch, G.A. and D.E. Baker. 1989. Fly ash erodibility. J. Soil Water Conserv. 44:624-627.

Matsi, T. and V.Z. Keramidas. 1999. Fly ash application on two acid soils and its effect on soil salinity, $\mathrm{pH}, \mathrm{B}, \mathrm{P}$ and on ryegrass growth and composition. Environ. Pollution 104:107-112.
McCarty, G.W., R. Siddaramappa, R.J. Wright, E.E. Codling, and G. Gao. 1994. Evaluation of coal combustion byproducts as soil liming materials: their influence on soil $\mathrm{pH}$ and enzyme activities. Biol. Fert. Soils. 17:197-172.

Mulhern, D.W., R.J. Robel, J.C. Furness, and D.L. Hensley. 1989. Vegetation of waste disposal areas at a coal-fired power plant in Kansas. J. Environ. Qual. 18:285-292.

Mulvaney, R.L. 1996. Nitrogen - inorganic forms. p. 1085-1122. In D.L. Sparks (ed.) Methods of Soil Analysis. Part 3. Chemical Methods. SSSA Book Ser. 5 SSSA and ASA, Madison, Wisc.

Page, A.L., A.A. Elseewi, and I.R. Straughan. 1979. Physical and chemical properties of fly ash from coal-fired power plants with reference to environmental impacts. Res. Rev. 71:83-120.

Rhoades, J.D. 1996. Salinity: Electrical conductivity and total dissolved solids. p. 417-436. In D.L. Sparks (ed.) Methods of Soil Analysis. Part 3. Chemical Methods. SSSA Book Ser. 5 SSSA and ASA, Madison, Wisc.

Sajwan, K.S., W.H. Ornes, and T. Youngblood. 1995. The effects of fly ash/sewage sludge mixtures and application rates on biomass production. J. Environ. Sci. Health A30:1327-1337.

Salo, L.F., J. F. Artiola, and J.W. GoodrichMahoney. 1999. Evaluation of revegetation techniques of a saline flue gas desulfurization sludge pond. J. Environ. Qual. 28:218-225.

Soil Survey Staff. 1965. Soil survey of Finney County Kansas. USDA, Washington D.C. 